\title{
Maturational Changes in Glutamine Transport by Rat Jejunal Brush Border Membrane Vesicles
}

\author{
FADHEELA $T$. AL-MAHROOS, NADA BULUS, NAJI ABUMRAD, HAMID SAID, AND \\ FAYEZ K. GHISHAN \\ Department of Pediatrics, Division of Pediatric Gastroenterology and Nutrition, Vanderbilt University Medical \\ School, Nashville, Tennessee 37232
}

\begin{abstract}
The ontogeny of glutamine uptake by jejunal brush border membrane vesicles was studied in suckling and weanling rats and compared with the data obtained from previous studies done on adult rats in our laboratory. Glutamine uptake represented transport into the intravesicular space rather than mere binding into the membrane as evident by osmolality study. The process of glutamine uptake was temperature dependent suggesting a carriermediated process with a $\mathrm{pH}$ optimum at 7.0 . Glutamine uptake was driven by $\mathrm{Na}^{+}$and $\mathrm{K}^{+}$gradient in both suckling and weanling rats. Both processes exhibited saturation kinetics and were inhibited by other neutral amino acids suggesting the presence of $\mathrm{Na}^{+}$-dependent neutral brush border system and $\mathrm{Na}^{+}$-independent $(L)$-like system. The $V_{\text {max }}$ of $\mathrm{Na}^{+}$-dependent and $\mathrm{Na}^{+}$-independent processes were significantly greater in suckling rats with $\mathrm{V}_{\max }$ of 4.9 $\pm 0.36 \mathrm{nmol} \cdot \mathrm{mg}$ protein ${ }^{-1} .7 \mathrm{~s}^{-1}$ compared to weanling rats with $V_{\max }$ of $2.4 \pm 0.2 \mathrm{nmol} \cdot \mathrm{mg} \mathrm{protein}^{-1} .7 \mathrm{~s}^{-1}$ and adult rats with $V_{\max }$ of $0.70 \mathrm{nmol} \cdot \mathrm{mg}$ protein ${ }^{-1} \cdot 7 \mathrm{~s}^{-1}$. The greater $V_{\max }$ in suckling rats is also evident when the kinetic parameters are analyzed by subtracting the sodium-dependent uptake values from the sodium-independent values. $V_{\max }$ of $1.59 \pm 0.3$ and $0.76 \pm 0.01 \mathrm{nmol} \cdot \mathrm{mg}$ protein ${ }^{-1}$. $7 \mathrm{~s}^{-1}$ in suckling and weanling rats, respectively, $p<0.01$. $\mathrm{Km}$ values were not different at $2.5 \pm 0.6$ and $3.5 \pm 0.6$ $\mathrm{mM}$, respectively). The data suggest that the activity and/ or the number of transporters are greater during the period of active growth and development. We conclude that glutamine transport in brush border membrane vesicles undergoes age-dependent changes with greater maximal capacity to transport glutamine in the suckling period. (Pediatr Res 27: 519-524, 1990)
\end{abstract}

\section{Abbreviations}

BBMV, brush border membrane vesicles

NBB, neutral brush border system

HEPES, $N$-2-hydroxyethylpiperazine- $N^{\prime}$-2-ethanesulfonic acid

BCH, $(\beta-2$ amino bicyclo $(2,2,1)$ heptane-2-carboxylic acid)

The developing intestine is characterized by very rapid growth with a daily protein turnover that exceeds $100 \%$ (1). The maturational process in the gastrointestinal tract includes morpho-

Received June 30. 1989: accepted December 27, 1989.

Correspondence: Fayez K Ghishan, M.D., Department of Pediatrics, Division of Pediatric Gastroenterology and Nutrition, Vanderbilt University Medical School, Nashville, TN 37232.

Supported by NIH Grant DK 41274-02. logic, biochemical, and functional changes to meet the demand of the organism for growth and development.

One of the important aspects of the metabolic activities in the intestine relates to glutamine metabolism. Although most body tissues use glucose as a source of energy, the intestine derives $>70 \%$ of its energy supply from glutamine metabolism (arterial and luminal) (2) and the resultant nitrogen atoms are used for the synthesis of citrulline, which is used for the synthesis of arginine in the kidney (3). Arginine is of importance in protein synthesis, especially during active periods of growth.

Because of this increased recognition of the importance of glutamine for the growing intestine, the present studies were designed to investigate the maturational processes in glutamine transport by brush border membranes of the jejunal enterocytes of the rat.

\section{MATERIALS AND METHODS}

Materials. $\mathrm{L}-\left[\mathrm{G}_{-}{ }^{3} \mathrm{H}\right]-\mathrm{Glutamine}$ (sp act $39 \mathrm{Ci} / \mathrm{mmol}$ ) and scintillation fluid (ACS) were purchased from Amersham/Searle (Des Plaines, IL). Unlabeled glutamine and other amino acids were purchased from Sigma Chemical Company (St. Louis, MO). Cellulose nitrate filters, $0.45 \mu \mathrm{m}$ pore size were obtained from Sartorius Filters, Inc (Hayward, CA). All other chemicals and reagents were obtained commercially and were of analytical quality.

Preparation of $B B M V$. Sprague-Dawley littermate rats were purchased from Sasco Laboratories (Omaha, NE). Suckling rats ( 2 wk old) and weanling rats ( $3 \mathrm{wk}$ old) were killed by cervical spine dislocation. The entire jejunum from the ligament of Treitz to approximately $13 \mathrm{~cm}$ distally was removed and flushed with ice-cold normal saline and then everted on a plastic rod. The mucosal scrapings were obtained from 8-10 rats and the BBMV were isolated by the modified Kessler's divalent cations $\left(\mathrm{Mg}^{2+}\right)$ precipitation technique (4). Preparations were maintained at approximately $4^{\circ} \mathrm{C}$ throughout the procedure. The mucosal scrapings were placed in $30 \mathrm{~mL}$ of buffer $\mathrm{I}$, which consisted of $300 \mathrm{mM}$ mannitol, $12 \mathrm{mM}$ Tris- $\mathrm{HCl}$ ( $\mathrm{pH}$ 7.4) and 5 mM EGTA, then $120 \mathrm{~mL}$ of ice-cold distilled water was added and the prep was homogenized for $3 \mathrm{~min}$ at maximum speed in an Omni mixer (Fisher Scientific Co., Pittsburgh, PA). The homogenate was then treated with $1.5 \mathrm{~mL}$ of $1 \mathrm{M} \mathrm{MgCl}_{2}$ and allowed to stand for $15 \mathrm{~min}$, followed by centrifugation at $3000 \mathrm{~g}$ for $15 \mathrm{~min}$ in a centrifuge model J2-21 (Beckman Instruments, Fullerton, CA). The pellet was discarded and the supernatant centrifuged at 27 $000 \mathrm{~g}$ for $30 \mathrm{~min}$. The resulting pellet was resuspended in $30 \mathrm{~mL}$ of buffer II, which consisted of $60 \mathrm{mM}$ mannitol, $12 \mathrm{mM}$ Tris-

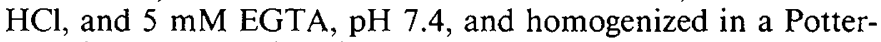
Elvehjem homogenizer for 10 strokes at maximum speed. The homogenate was treated with $0.3 \mathrm{~mL}$ of $1 \mathrm{M} \mathrm{MgCl}_{2}$, allowed to stand for $15 \mathrm{~min}$ at $0^{\circ} \mathrm{C}$, then centrifuged at $3000 \times g$ for 15 min. The pellet was discarded and the supernatant centrifuged at $27000 \times g$ for $30 \mathrm{~min}$. The resulting pellet was resuspended 
in $30 \mathrm{~mL}$ of buffer III, which consisted of $300 \mathrm{mM}$ mannitol and $30 \mathrm{mM}$ HEPES/Tris at $\mathrm{pH} 7.4$ and homogenized in a Potter homogenizer for 10 strokes at the highest speed. The homogenate was then centrifuged at $50000 \times g$ for $30 \mathrm{~min}$ and the resulting pellet was resuspended in the desired volume of transport buffer, using tuberculin syringe with a 25 -gauge needle.

Purity of membrane vesicle preparation was assessed by the measurement of disaccharidases as described by Dahlquist (5), leucine aminopeptidase by Boehringer kit no. 124869 (Boehringer-Mannheim Biochemicals, Indianapolis, IN), $\mathrm{Na}^{+}-\mathrm{K}^{+}$ATPase by the method of Scharschmidt et al. (6), and cytochrome-Coxidase and NADPH cytochrome-C-reductase as described by Beaufay et al. (7). Protein assay was done by the method of Lowry et al. (8).

Transport measurements. Uptake of ${ }^{3} \mathrm{H}$-glutamine by BBMV was measured by a rapid filtration technique (5). All experiments were performed at $25^{\circ} \mathrm{C}$ unless specified otherwise in the figure legends. Transport was initiated by the addition of $20 \mu \mathrm{L}$ aliquot of membrane vesicle suspension to $80 \mu \mathrm{L}$ of the desired incubation media containing ${ }^{3} \mathrm{H}$-glutamine as described in the figure legends. At the desired time intervals, the reaction was stopped by the addition of $1 \mathrm{~mL}$ ice-cold stop solution. The suspension containing the vesicle was immediately pipetted onto the middle of a cellulose nitrate filter $(0.45 \mathrm{~mm}$ pore size Sartorius filters) kept under suction and immediately washed with $5 \mathrm{~mL}$ ice-cold stop solution. The stop solution consisted of $100 \mathrm{mM}$ mannitol, $100 \mathrm{mM} \mathrm{NaCl}$, and $20 \mathrm{mM} \mathrm{HEPES} /$ Tris, $\mathrm{pH} \mathrm{7.4.} \mathrm{A} \mathrm{liquid}$ scintillation counter (Model LS 3801, Beckman Instruments, Palo Alto, CA) was used to determine the amount of radioactive substrate remaining on the filter with Ready protein ${ }^{+}$(Beckman Instruments) used as a liquid scintillant. Radioactivity remaining in the filters after pipetting, an identical solution without vesicles, was used as a background and subtracted from the uptake data. Ten to 12 suckling and six to eight weanling rats were used for each vesicle preparation. The values depicted in the tables and figures represent mean of uptake points from two to three vesicle preparations. Each vesicle preparation was run in triplicates $(n$ $=6-9$ ). The uptake data are expressed in $\mathrm{pmol} / \mathrm{mg}$ protein per unit time.

Statistical evaluation. All data were statistically analyzed and expressed as mean \pm SE. Two-tailed $t$ test was used to evaluate the significance of data differences. A $p$ value $<0.05$ was considered statistically significant.

\section{RESULTS}

Purity of membrane vesicles. The brush border enzyme markers (leucine aminopeptidase and disaccharidases) showed a 10 to 14-fold enrichment in BBMV compared to mucosal homogenate. There was an impoverishment in $\mathrm{Na}^{+}-\mathrm{K}^{+}$ATPase enzyme activity, a marker for basolateral membranes, cytochrome oxidase, a marker of mitochondrial enzymes, and NADH-cytochrome-C-reductase, a marker for endoplasmic reticulum (9).

Glutamine transport versus binding. To determine whether glutamine uptake represents binding or transmembrane movement, two studies were conducted in 3-wk-old rats. First, an osmotic sensitivity was done in which the intravesicular space was decreased by increasing the osmolarity of the incubation media from 200-700 mosmol by the addition of mannitol in increasing concentration. The uptake of glutamine was then determined at $10 \mathrm{~min}$. Figure 1 shows that the uptake of glutamine was inversely related to media 1/osmolarity, as depicted by the equation $\mathrm{Y}=-8.5+13 \mathrm{x}$ with $r=0.98$. Second, a temperature dependency study was done in which glutamine uptake was determined at 0 and $25^{\circ} \mathrm{C}$. Figure 2 shows that glutamine uptake was significantly greater at $25^{\circ} \mathrm{C}$ compared to $0^{\circ} \mathrm{C}(p<0.05-0.001$ for all values $)$.

To evaluate the degree of glutamine metabolized by brush border membranes, vesicles were incubated with $25 \mathrm{mM}$ gluta-

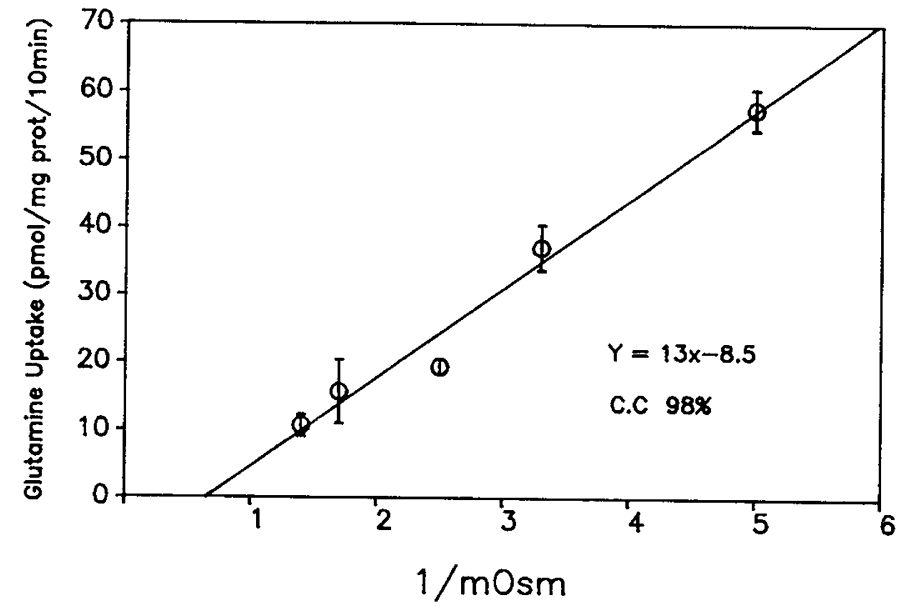

Fig. 1. Effect of media osmolality on glutamine uptake. BBMV from weanling rats were preincubated in $300 \mathrm{mM}$ mannitol and $20 \mathrm{mM}$ HEPES/Tris buffer, $\mathrm{pH}$ 7.4. The incubation media consisted of $100 \mathrm{mM}$ $\mathrm{NaCl}, 20 \mathrm{mM}$ HEPES/Tris buffer, and varying concentrations of mannitol $(0-500)$ to yield osmolarity from $200-700$ mosmol in addition to $0.02 \mathrm{mM}$ glutamine and $0.5 \mu \mathrm{Ci}^{3} \mathrm{H}$ glutamine. The reaction was started by the addition of $20 \mu \mathrm{L}$ vesicles to the variable incubation medium and the reaction stopped at $10 \mathrm{~min}$. The experiments were done in triplicate and the data represents the mean \pm SE.

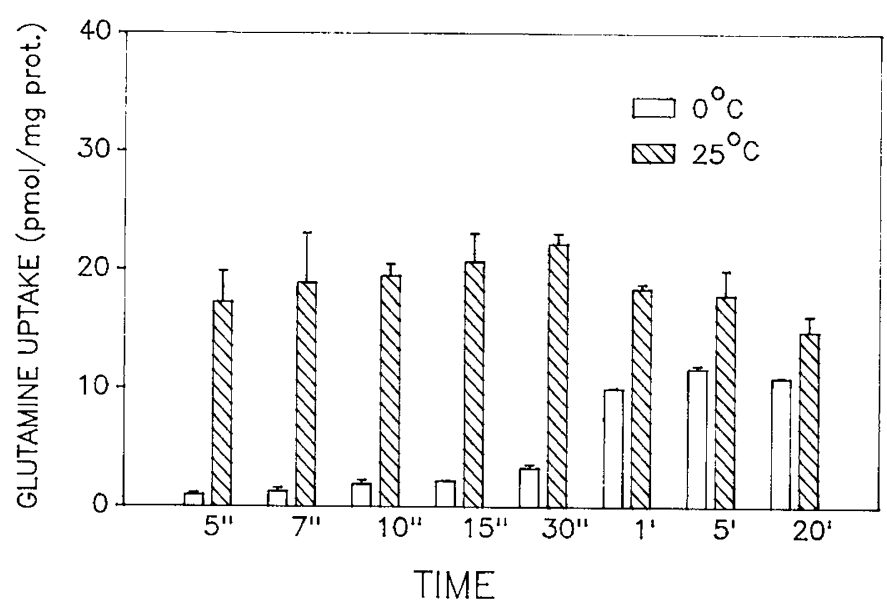

Fig. 2. Effect of temperature on glutamine uptake. BBMV were preincubated in $300 \mathrm{mM}$ mannitol and $20 \mathrm{mM}$ HEPES/Tris buffer pH 7.4. The incubation media consisted of $100 \mathrm{mM}$ mannitol, $100 \mathrm{mM} \mathrm{NaCl}$, and $20 \mathrm{mM} \mathrm{HEPES/Tris} \mathrm{buffer,} \mathrm{pH} 7.4$, in addition to $0.02 \mathrm{mM}$ glutamine and $0.5 \mu \mathrm{Ci}^{3} \mathrm{H}$ glutamine. Reaction was started by the addition of $20 \mu \mathrm{L}$ membrane vesicles to the incubation medium and the reaction stopped at the time interval shown in the figure. The experiments were done in triplicate and the data represents the mean \pm SE.

mine. Glutamine and glutamate were determined at various time points by a well-validated enzymatic method (10). At $10 \mathrm{~min}$, no significant degree of metabolism could be noted. At $20 \mathrm{~min}$, $10 \%$ of the glutamine was recovered as glutamate.

Effect of $\mathrm{Na}^{+}$and $\mathrm{K}^{+}$gradients on glutamine uptake. Glutamine uptake was determined in both suckling and weanling rats under inwardly directed sodium and potassium gradients. The uptake of glutamine was stimulated by both sodium and potassium gradient with "overshoot" phenomena. The "overshoot" with $\mathrm{K}^{+}$is a quite unusual phenomenon in transport studies using vesicles. The magnitude of the uptake was greater with $\mathrm{Na}^{+}$gradient compared with $\mathrm{K}^{+}$gradient (Fig. 3). In addition, in suckling rats the peak "overshoot" was significantly greater than in corresponding values in weanling rats $68.0 \pm 8.0$ versus $21 \pm$ $0.3 \mathrm{pmol} \cdot \mathrm{mg}$ protein ${ }^{-1}$ with $p<0.05$. Although values at $20 \mathrm{~min}$ were different between $\mathrm{Na}^{+}$and $\mathrm{K}^{+}$gradient, previous studies in 


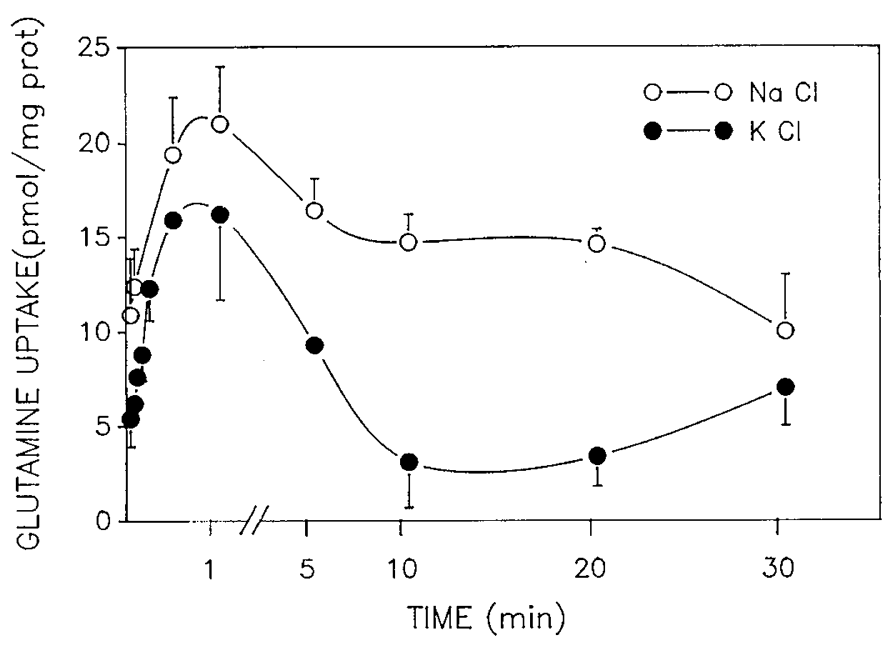

Fig. 3. Effect of $\mathrm{Na}^{+}$and $\mathrm{K}^{+}$gradient on glutamine uptake. BBMV were prepared from weanling rats and preincubated in $300 \mathrm{mM}$ mannitol and $20 \mathrm{mM}$ HEPES/Tris buffer, $\mathrm{pH}$ 7.4. The reaction was started by the addition of $20 \mu \mathrm{L}$ membrane vesicles to either $100 \mathrm{mM} \mathrm{NaCl}, 100 \mathrm{mM}$ mannitol, and $20 \mathrm{mM}$ HEPES/Tris buffer, pH 7.4 or $100 \mathrm{mM} \mathrm{KCl}, 100$ $\mathrm{mM}$ mannitol, and $20 \mathrm{mM}$ HEPES/Tris buffer, $\mathrm{pH}$ 7.4. Glutamine concentration was $0.02 \mathrm{mM}$. Reaction was stopped at variable points of time as shown. The experiments were done in triplicate and the data represent the mean $\pm \mathrm{SE}$.

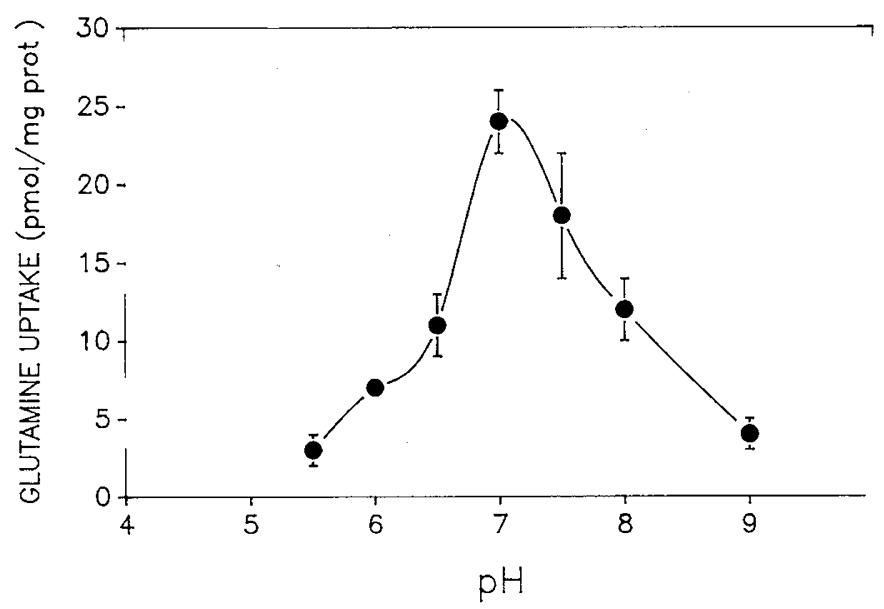

Fig. 4. Effect of $\mathrm{pH}$ on glutamine uptake. BBMV were prepared in $300 \mathrm{mM}$ mannitol and $20 \mathrm{mM}$ HEPES/Tris buffer, $\mathrm{pH}$ 7.4. The incubation media consisted of $100 \mathrm{mM} \mathrm{NaCl}, 100 \mathrm{mM}$ mannitol, and 20 $\mathrm{mM}$ HEPES/Tris buffer, pH 5.5-9, in addition to $0.02 \mathrm{mM}$ and $0.5 \mu \mathrm{Ci}$ ${ }^{3} \mathrm{H}$ glutamine. Reaction was started by the addition of $20 \mu \mathrm{L}$ membrane vesicles to each incubation medium and the reaction was stopped at 15 $\mathrm{s}$. The experiments were done in triplicate and the data represents the mean $\pm \mathrm{SE}$

our laboratory indicated similar vesicle size in membranes of suckling and adult rats using mannitol uptake studies (9). To study the effect of an outwardly directed $\mathrm{K}^{+}$gradient on glutamine uptake, vesicles were loaded with $\mathrm{KCl}$ solution of various concentrations $(100,50,0 \mathrm{mM})$ and glutamine uptake was measured under an inwardly directed $\mathrm{Na}^{+}$gradient. Uptake values were $11.6 \pm 2,11.3 \pm 2$ and $10 \pm 2 \mathrm{pmol} \cdot \mathrm{mg}$ protein ${ }^{-1}$. $10^{-1}$ respectively $(p>0.05)$.

pH optimum of glutamine uptake. Figure 4 shows glutamine uptake in weanling rats at different incubation media $\mathrm{pH}$ that varied from 5.5 to 9 . Optimal uptake was noted at a $\mathrm{pH}$ of 7.0 with severe inhibition at 5.5 and 9.0 .

Effect of membrane potential on glutamine uptake. To demonstrate the electrical potential dependence of sodium-coupled glutamine transport, two studies were conducted. In the first study, valinomycin, a potassium selective ionophore that mediates the electrogenic movement of $\mathrm{K}^{+}$down its concentration gradient, was used to create an electrochemical potential across the membrane (11-16). In Figure 5, with increased interior negativity $\left(\mathrm{K}^{+}\right.$inside $>\mathrm{K}^{+}$outside in the presence of valinomycin), there was a significant enhancement of $\mathrm{Na}^{+}$-coupled glutamine uptake compared to voltage clamp condition $(\mathrm{K}$ inside $=$ $\mathrm{K}$ outside + valinomycin).

The second study was an anion substitution study. Sodium thiocyanate is a highly permeable anion compared to sodium sulfate with sodium chloride being intermediate $(12,14)$. A faster influx of thiocyanate into the BBMV creates a negatively charged inside with more uptake of glutamine compared with the sodium sulfate and sodium chloride. This study showed that glutamine uptake was $46 \pm 3 \mathrm{pmol} \cdot \mathrm{mg}$ protein ${ }^{-1} \cdot 30 \mathrm{~s}^{-1}$ with sodium thiocyanate compared with $24 \pm 3 \mathrm{pmol} \cdot \mathrm{mg}$ protein ${ }^{-1} \cdot 30 \mathrm{~s}^{-1}$ with sodium sulfate. Both of these studies are strong indicators that $\mathrm{Na}^{+}$-coupled glutamine transport is rheogenic in nature. A similar study with $\mathrm{K}^{+}$gradient showed no difference in glutamine uptake with different anions indicating that the $\mathrm{Na}^{+}$independent uptake of glutamine is electroneutral.

Kinetics of glutamine uptake. Kinetic experiments were carried out under initial rate conditions with a substrate concentration that ranged from $0.2-10 \mathrm{mM}$. Kinetic parameters were analyzed using a computerized model of Michaelis-Menten kinetics (17). In suckling and weanling rats, a saturable process was observed in the presence and absence of sodium gradient. This is in agreement with our previous findings in adult rats where a saturable process was observed under both $\mathrm{Na}^{+}$gradient and $\mathrm{K}^{+}$ gradient conditions. However, as shown in Figure 6 for the $\mathrm{Na}^{+}-$ dependent system, the $\mathrm{V}_{\max }$ in suckling rats was significantly greater compared to corresponding mean values in weanling rats, $4.9 \pm 0.36$ versus $2.4 \pm 0.2 \mathrm{nmol} \cdot \mathrm{mg}$ protein ${ }^{-1} .7 \mathrm{~s}^{-1}(p<0.01)$, whereas the $\mathrm{Km}$ being $3.84 \pm 0.6 \mathrm{mM}$ in suckling rats versus 2.7 $\pm 0.6 \mathrm{mM}$ in weanling rats. Furthermore, our previous studies with adult rats (18) showed a lower $V_{\max }$ of $0.70 \mathrm{nmol} \cdot \mathrm{mg}$ protein ${ }^{-1} \cdot \mathrm{s}^{-1}$ while the $\mathrm{Km}$ was similar at $3.5 \mathrm{mM}$ for the $\mathrm{Na}^{+}-$ dependent system. Figure 7 depicts the $\mathrm{Na}^{+}$-independent system in suckling and weanling rats. The $\mathrm{V}_{\max }$ in suckling rats was

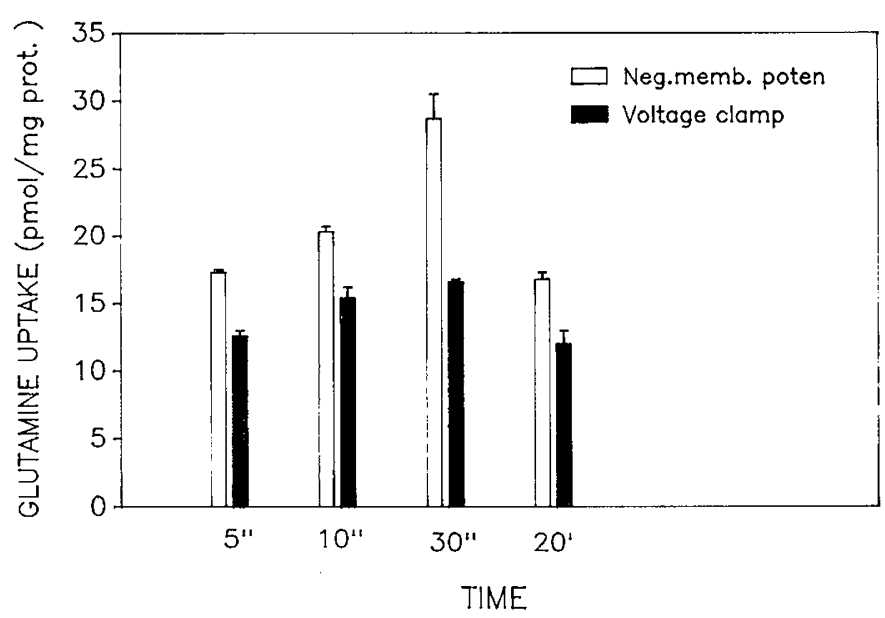

Fig. 5. Effect of membrane potential on glutamine uptake. BBMV were preincubated in $50 \mathrm{mM} \mathrm{KCl}, 200 \mathrm{mM}$ mannitol, and $20 \mathrm{mM}$ HEPES/Tris buffer, pH 7.4. BBMV were then incubated in a media containing either $100 \mathrm{mM} \mathrm{NaCl}, 50 \mathrm{mM} \mathrm{KCl}, 20 \mathrm{mM} \mathrm{HEPES} / \mathrm{T}$ ris buffer, $\mathrm{pH} 7,0.5 \mu \mathrm{Ci}^{3} \mathrm{H}$ glutamine, $0.02 \mathrm{mM}$ glutamine, and valinomycin $10 \mu \mathrm{g} / \mathrm{mg}$ protein (voltage clamp) or in a media containing $100 \mathrm{mM}$ $\mathrm{NaCl}, 10 \mathrm{mM} \mathrm{KCl}, 20 \mathrm{mM}$ HEPES, $\mathrm{pH} 7.0,0.5 \mu \mathrm{Ci}^{3} \mathrm{H}$ glutamine, 0.02 $\mathrm{mM}$ glutamine, and valinomycin (negative membrane potential). Reaction was started by the addition of $20 \mu \mathrm{L}$ membrane vesicles to each incubation medium and the reaction was stopped at the time intervals shown above. The experiments were done in triplicate and the data represent the mean $\pm \mathrm{SE}$. 


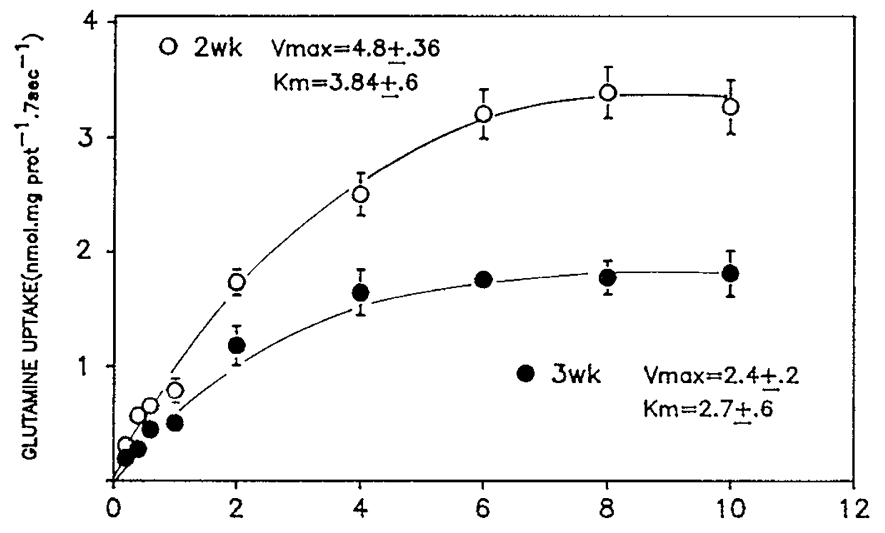

GLN. CONCENTRATION(mM)

Fig. 6. Kinetics of the $\mathrm{Na}^{+}$dependent system in 2- and 3-wk old rats. BBMV were preincubated in $300 \mathrm{mM}$ mannitol and $20 \mathrm{mM}$ HEPES/ Tris buffer, $\mathrm{pH}$ 7.4. The incubation media consisted of $100 \mathrm{mM}$ mannitol, $100 \mathrm{mM} \mathrm{NaCl}$, and $20 \mathrm{mM}$ HEPES/Tris buffer, $\mathrm{pH}$ 7.4. In addition to $0.5 \mu \mathrm{Ci}{ }^{3} \mathrm{H}$ glutamine, the media contained different glutamine concentrations that ranged from $0.1-10 \mathrm{mM}$. The reaction was started by the addition of $20 \mu \mathrm{L}$ membrane vesicles to the different incubation media and the reaction was stopped at $7 \mathrm{~s}$. The experiments were done in triplicate and the data represent the mean $\pm \mathrm{SE}$.

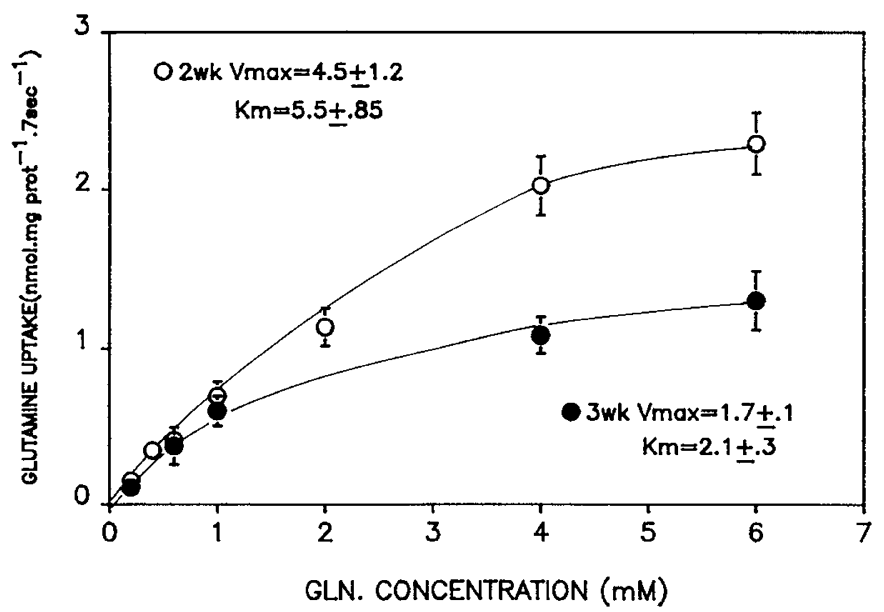

Fig. 7. Kinetics of the $\mathrm{Na}^{+}$-independent System in 2- and 3-wk old rats. BBMV were preincubated in $300 \mathrm{mM}$ mannitol and $20 \mathrm{mM}$ HEPES/Tris buffer, pH 7.4. The incubation media consisted of $100 \mathrm{mM}$ mannitol, $100 \mathrm{mM} \mathrm{KCl}$, and $20 \mathrm{mM}$ HEPES/Tris buffer, $\mathrm{pH}$ 7.4. In addition to $0.5 \mu \mathrm{Ci}^{3} \mathrm{H}$ glutamine, the media contained different glutamine concentrations that ranged from $0.1-6 \mathrm{mM}$. The reaction was started by the addition of $20 \mu \mathrm{L}$ membrane vesicles to the different incubation media and the reaction was stopped at $7 \mathrm{~s}$. The experiments were done in triplicate and the data represent the mean $\pm \mathrm{SE}$

significantly greater compared with corresponding values in weanling rats, $4.5 \pm 0.1$ versus $1.7 \pm 0.1$ nmoles $\cdot \mathrm{mg}_{\text {protein }}{ }^{-1}$. $7 \mathrm{~s}^{-1}(p<0.001)$ whereas the $\mathrm{Km}$ was $5.5 \pm 0.85$ versus $2.1 \pm$ 0.3 , respectively. Similarly, adult rat studies showed a lower $V_{\max }$ of $0.281 \mathrm{nmol} \cdot \mathrm{mg}$ protein ${ }^{-1} .7 \mathrm{~s}^{-1}$, whereas the $\mathrm{Km}$ was similar at $3.34 \mathrm{mM}$ for the $\mathrm{Na}^{+}$-independent system (18). When the kinetic parameters were subjected to analysis using the values representing the differences between uptake in the presence of sodium gradient minus the sodium-independent values, the $V_{\max }$ in the suckling rat was still significantly greater, $1.59 \pm 0.3$ compared to corresponding values in weanling rats of $0.76 \pm 0.1$ $\mathrm{nmol} \cdot \mathrm{mg}$ protein ${ }^{-1} \cdot 7 \mathrm{~s}^{-1}(p<0.01)$. Km values were not different at $2.5 \pm 0.6$ and $3.5 \pm 0.6 \mathrm{mM}$, respectively.

Effect of neutral amino acids on glutamine uptake. Table 1 shows that most neutral amino acids, especially asparagine and histidine, inhibited ${ }^{3} \mathrm{H}$ glutamine uptake. In contrast, 2-(methyl amino)isobuturic acid, $\beta$-alanine, $\mathrm{BCH}$, methionine, and phenylalanine showed minimal inhibition of glutamine uptake in adults, suckling, and weanling rats. This pattern is suggestive of system NBB and not system A $(19,20)$.

Table 2 similarly shows that several neutral amino acids inhibited glutamine uptake. The degree of inhibition was greater with leucine and $\mathrm{BCH}$. This pattern is suggestive of an L-like system (21) and was similar in all age groups.

Effect of lithium substitution on glutamine uptake. In this study, glutamine uptake was determined under inwardly directed $\mathrm{Na}^{+}$, lithium, and choline gradient. As shown in Figure 8, the uptake of glutamine was significantly lower with lithium and choline in adult, weanling, and suckling rats.

\section{DISCUSSION}

The present studies were designed to characterize the maturational changes in glutamine transport by intestinal BBMV in suckling and weanling rats.

The enterocyte of the jejunum receives large amounts of glutamine from two sources: the luminal side and the basolateral side. Both sources utilize the same enzyme within the enterocytes. Windmueller et al. (22) described the regulation of glutamine metabolism by the enterocytes by both sources of glutamine. At luminal concentration of $6 \mathrm{mM}$ in the luminal side, glutamine uptake and metabolism from the arterial side was reduced by $40 \%$. Therefore, both sources of glutamine act as a metabolic unit for the jejunum. More recently, Taylor et al. (23) presented data to suggest that glutamine transport by the basolateral membranes is not affected by the presence of glutamine in the lumen, arguing against the concept of a common pool of glutamine from luminal and basolateral sources. Intestinal energy production is required to support a number of functions: rapid cellular growth, differentiation, cell migration, and absorptive processes. Active glutamine metabolism has been correlated with rapid cellular growth. For example, activity of glutaminase increases 3-fold during log phase growth in human diploid fibroblasts compared to confluent cultures (24). Moreover, glutaminase activity doubles between d 12 and 15 after birth (25). This observation correlates with that period of intestinal development when there are marked increases in proliferation (1). Therefore, the current studies were designed to investigate and characterize glutamine transport in suckling and weanling rats.

The uptake of a solute by an isolated membrane fraction can be composed of transport into an intravesicular compartment and/or binding to the membrane surface (26). Two possible ways to distinguish between these two components of uptake are osmotic sensitivity and temperature dependency. The osmolarity study based on the fact that the amount of glutamine transported into the intravesicular space should be, under equilibrium conditions, in direct relation to the intravesicular volume. With decreasing the intravesicular volume, the uptake of glutamine should decrease proportionately to the decrease in the vesicular space. The equation depicting the relationship between uptake and 1/osmolarity suggests clearly that the uptake of glutamine by the BBMV represents a transport into the intravesicular space rather than binding into the membrane surface. These findings were substantiated by studies of temperature dependency showing a significant inhibition of uptake at $0^{\circ} \mathrm{C}$ compared with $25^{\circ} \mathrm{C}$, which indicates the presence of a carrier-mediated transport system (27). Similar findings were obtained with adult rats (18).

The imposition of inwardly directed sodium and potassium gradients stimulated glutamine uptake with "overshoot" phenomena under both conditions in suckling and weanling rats alike. However, the magnitude of the enhancement of uptake was greater with sodium gradient compared with potassium gradient in weanling rats, while it was the same in suckling rats. In addition, in suckling rats the peak of "overshoot" under both 
Table 1. Percent of inhibition of ${ }^{3} \mathrm{H}$ Gln uptake by various amino acids with inwardly directed $\mathrm{Na}^{+}$gradient $^{*}$

\begin{tabular}{cccccccccccccccc}
\hline \multicolumn{110}{c}{ Amino acid } \\
\hline Rats & Control & Gln & Gly & Met & Phe & MeAIB & $\beta$-Ala & Asn & His & Leu & Val & BCH & Ser & Cys & Systems \\
\hline Adult & 100 & $68 \pm 6$ & $16 \pm 2$ & 0 & $8 \pm 0.4$ & 0 & $5 \pm 0.5$ & $49 \pm 3$ & $79 \pm 6$ & $29 \pm 1$ & $50 \pm 4$ & $3 \pm 0.4$ & $34 \pm 2$ & $28 \pm 2$ & NBB \\
3-wk-old & 100 & $61 \pm 6$ & $13 \pm 5$ & $3.6 \pm 1$ & $4 \pm 2$ & 0 & $2.5 \pm 0.1$ & $44 \pm 2$ & $40 \pm 3$ & 0 & $24 \pm 3$ & $10 \pm 1$ & $26 \pm 2$ & $31 \pm 3$ & NBB \\
2-wk-old & 100 & $69 \pm 4$ & $26 \pm 1$ & 0 & $10 \pm 0.4$ & 0 & $2.6 \pm 0.2$ & $40 \pm 2$ & $30 \pm 1$ & $2.6 \pm 0.4$ & $13 \pm 1$ & $26 \pm 2$ & $32 \pm 2$ & $26 \pm 3$ & NBB \\
\hline
\end{tabular}

* BBMV from suckling, weanling, and adult rats were preincubated in $300 \mathrm{mM}$ mannitol and $20 \mathrm{mM}$ HEPES/Tris, $\mathrm{pH}$ 7.4. The incubation media consisted of $100 \mathrm{mM} \mathrm{NaCl}, 100 \mathrm{mM}$ mannitol, and $20 \mathrm{mM}$ HEPES/Tris, $\mathrm{pH} 7.4$, in addition to $2 \mathrm{mM}$ glutamine, $0.5 \mu \mathrm{Ci},{ }^{3} \mathrm{H}$ glutamine, and various amino acids at a concentration of $20 \mathrm{mM}$. The reaction was started by the addition of $20 \mu \mathrm{L}$ vesicles to the incubation media and the reaction was stopped at $60 \mathrm{~s}$. The experiments were done in triplicate and the data represents the mean \pm SE. MeAIB, 2-(methyl amino)isobuturic acid.

Table 2. Percent of inhibition of ${ }^{3} \mathrm{H}$ Gln uptake by various amino acids with inwardly directed $K^{+}$gradient*

\begin{tabular}{ccccccccccccccccc}
\hline \multicolumn{11}{c}{ Amino acid } \\
\hline Rats & Control & Gln & Gly & Met & Phe & MeAlB & $\beta$-Ala & Asn & His & Leu & Val & BCH & Ser & Cys & Systems \\
\hline Adult & 100 & $67 \pm 3$ & $5 \pm 0.5$ & 0 & $38 \pm 3$ & 0 & $16 \pm 2$ & $10 \pm 1$ & $23 \pm 2$ & $61 \pm 6$ & 0 & $68 \pm 7$ & $23 \pm 2$ & $3 \pm 0.3$ & $\mathrm{~L}$ \\
3-wk-old & 100 & $73 \pm 6$ & $15 \pm 2$ & $1.5 \pm 0.2$ & $22 \pm 0.5$ & $9.5 \pm 1$ & $15 \pm 1$ & $11 \pm 0.2$ & $17 \pm 1$ & $76 \pm 5$ & $42 \pm 2$ & $34 \pm 2$ & $30 \pm 2$ & $36 \pm 3$ & $\mathrm{~L}$ & \\
2-wk-old & 100 & $72 \pm 5$ & $35 \pm 3$ & 0 & $23 \pm 1$ & $18 \pm 2$ & $14 \pm 0.8$ & $7 \pm 0.6$ & $4.6 \pm 0.4$ & $81 \pm 6$ & $27 \pm 2$ & $72 \pm 4$ & $27 \pm 3$ & $25 \pm 2$ & $\mathrm{~L}$ \\
\hline
\end{tabular}

* BBMV from suckling, weanling, and adult rats were preincubated in $300 \mathrm{mM}$ mannitol and $20 \mathrm{mM}$ HEPES/Tris, pH 7.4. The incubation media consisted of $100 \mathrm{mM} \mathrm{KCl}, 100 \mathrm{mM}$ mannitol, and $20 \mathrm{mM} \mathrm{HEPES} /$ Tris, $\mathrm{pH} 7.4$, in addition to $2 \mathrm{mM}$ glutamine, $0.5 \mu \mathrm{Ci},{ }^{3} \mathrm{H}$ glutamine, and various amino acids at a concentration of $20 \mathrm{mM}$. The reaction was started by the addition of $20 \mu \mathrm{L}$ vesicles to the incubation media and the reaction was stopped at $60 \mathrm{~s}$. The experiments were done in triplicate and the data represents the mean \pm SE. MeAIB, 2-(methyl amino)isobuturic acid.

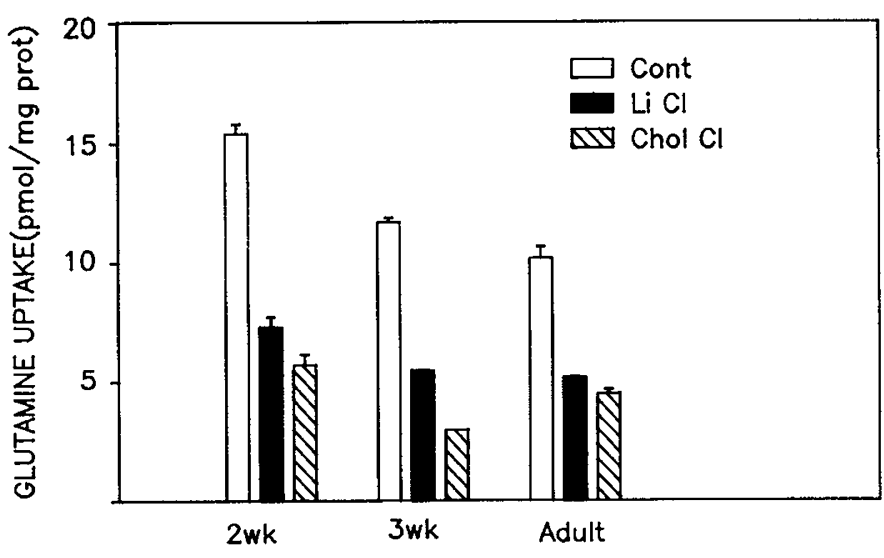

Fig. 8. BBMV from suckling, weanling, and adult rats were preincubated in $300 \mathrm{mM}$ mannitol and $20 \mathrm{mM}$ HEPES/Tris buffer, $\mathrm{pH}$ 7.4. The incubation media consisted of $100 \mathrm{mM}$ of either $\mathrm{NaCl}, \mathrm{LiCl}$ or choline chloride in addition to $0.02 \mathrm{mM}$ glutamine and $0.5 \mu \mathrm{Ci}{ }^{3} \mathrm{H}$ glutamine. The reaction was started by the addition of $20 \mu \mathrm{L}$ vesicles to the variable incubation media and the reaction was stopped at $1 \mathrm{~min}$. The experiments were done in triplicate and the data represent the mean $\pm \mathrm{SE}$.

$\mathrm{Na}^{+}$and $\mathrm{K}^{+}$gradient was significantly greater compared with values in weanling rats $68 \pm 8$ versus $21 \pm 0.3 \mathrm{pmol} \cdot \mathrm{mg}$ protein $^{-1}$. These results differ from our previous findings in adult rats, which showed a distinct enhancement of uptake only with $\mathrm{Na}^{+}$gradient and not with $\mathrm{K}^{+}$gradient.

These findings suggest that glutamine uptake by suckling and weanling BBMV is both sodium dependent and sodium independent. Both processes exhibit concentrative overshooting phenomena indicating an active, energy-dependent process. The kinetic properties of both processes exhibit ontogenic changes, with the $V_{\max }$ of both sodium-dependent and -independent processes being greater in suckling rats compared with weanling. The sodium-dependent process is electrogenic and $\mathrm{pH}$ dependent with maximum uptake at $\mathrm{pH} 7.0$, while the sodium-independent is electroneutral. Moreover, the rate of glutamine uptake in suckling rats is significantly greater compared with membranes in weanling rats. The finding of a greater $V_{\max }$ in the suckling rats suggest that the capacity and/or the activity of the transport carrier is greater compared with weanling and adult rats. These ontogenic changes may be related to greater demands during the active period of growth in the suckling period. These observations are supported by the finding of Kimura (28), which showed greater glutamine oxidation by jejunal slices of suckling rats compared to weanling. Although Kimura used jejunal slices that reflect events at both brush border and basolateral membranes, our unpublished observation suggests that the maturational events at the basolateral membranes mirrors that of the brush border membranes.

As shown in Table 1, most neutral amino acids, especially asparagine and histidine, inhibited ${ }^{3} \mathrm{H}$ glutamine uptake and showed minimal interaction with $\mathrm{BCH}$, a synthetic amino acid transported in a $\mathrm{Na}^{+}$-independent fashion. This pattern of inhibition is suggestive of the $\mathrm{Na}^{+}$-dependent $\mathrm{NBB}$ system as described in rabbit jejunal BBMV by Stevens et al. (21) and in dog jejunal BBMV as described by Bulus et al. (29). 2-(Methyl amino)isobuturic acid, the typical substrate for system A, which is well-characterized in other plasma cells, showed no inhibition. Lack or minimal inhibition by phenylalanine and methionine, the typical substrates of system PHE, indicates that glutamine is not transported via this $\mathrm{Na}^{+}$-dependent system either. The pattern of inhibition is similar in adult, weanling, and suckling rats. As shown in Figure 8, lithium failed to substitute for $\mathrm{Na}^{+}$in the three age groups, suggesting absolute specificity for $\mathrm{Na}^{+}$, unlike system $\mathrm{N}$ in other plasma cells, where lithium could substitute for $\mathrm{Na}^{+}$.

Although system L, in its original description in Ehrlich ascites tumor cells, is believed to be stereospecific for leucine, our study as well as others (21) showed that this system transports several neutral amino acids in intestinal BBMV. However, the degree of inhibition was larger with leucine and $\mathrm{BCH}$. This pattern is suggestive of the presence of an L-like system as described in intestinal BBMV in rabbits (21) and dogs (29).

We conclude that glutamine transport by BBMV undergoes maturational changes consistent with the existence of two different glutamine transporters that have greater capacity in younger groups. The first system is $\mathrm{Na}^{+}$-dependent $\mathrm{NBB}$, which transports most neutral amino acids, especially asparagine and histidine. This system is $\mathrm{pH}$ sensitive and lithium intolerant. The second 
system is $\mathrm{Na}^{+}$-independent L-like system, which transports several other neutral amino acids, especially leucine and $\mathrm{BCH}$.

\section{REFERENCES}

1. Herbst JJ, Sunshine P 1969 Postnatal development of the small intestine of the rat changes in mucosal pathology at weaning. Pediatr Res 3:27-33

2. Windmueller HG 1982 Glutamine utilization by the small intestine. Adv Enzymol 53:201-237

3. Windmueller HG, Spaeth AE 1981 Source and fate of circulating citrulline. Am J Physiol 241:E473-E480

4. Kessler M, Ocato O, Storelli C, Maurer H, Muller M, Semenza G 1978 A modified procedure for the rapid preparation of efficiently transporting vesicles from the small intestine brush border membrane. Biochim Biophys Acta 506:135-154

5. Dahlquist A 1964 Assay of intestinal disaccharidases. Anal Biochem 7:18-25

6. Scharschmidt BF, Keeffe EB, Blankenship NM, Ockner RK 1979 Validation of a recording spectrophotometric method for measurement of membrane associated $\mathrm{Mg}^{++}$and $\mathrm{Na}^{+} \mathrm{K}^{+}$-ATPase activity. $\mathrm{J}$ Lab Clin Med 93:790-799

7. Beaufay HA, Amas-Costesec AA, Feytmans E, Thines-Sempoux D, Wibo M, Robbi M, Berthet J 1974 Analytical study of microsomes and isolated subcellular membranes from rat liver. Biochemical methods. J Cell Biology 61:188-200

8. Lowry OH, Rosebrough NJ, Farr AL, Randall RJ 1951 Protein measurement with the folin phenol reagent. J Biol Chem 193:265-275

9. Ghishan FK, Wilson FA 1985 Developmental maturation of D-glucose transport by jejunal brush border vesicles. Am J Physiol 248:G87-G92

10. Cerosimo E, Williams PE, Radosevich PM, Hoxworth BT, Lacy WW, Abumrad NN 1986 Role of glutamine in adaptations in nitrogen metabolism during fasting. Am J Physiol E622-E628

11. Knickelbein R. Aronson PS, Atherton W, Dobbins OW 1983 Sodium and chloride transport across rabbit ileal brush border. 1 . Evidence for $\mathrm{Na}^{+}-\mathrm{H}^{+}$ exchange. Am J Physiol 245:G504-G510

12. Lucke H, Stauge G, Kinne R, Murer H 1978 Taurocholate sodium cotransport by brush border membrane vesicles isolated from rat ileum. Biochem 174:951-958

13. Murer H, Hildman B 1984 Pharmacology of Intestinal Permeation. SpringerVerlag, New York, pp 157-193

14. Rouse D, Lack L 1980 Short-term studies of taurocholate uptake by ileal brush border membrane vesicles. Biochem Biophys Acta 599:324-329
15. Ganapathy V, Leibach FH 1983 Role of $\mathrm{pH}$ gradient and membrane potential in dipeptide transport in intestinal and renal brush border membrane vesicles from the rabbit. J Biol Chem 258:14189-14192

16. Wilson F, Treanor LL 1979 Glycodeoxycholate trnasport in brush border membrane vesicles isolated from rat jejunum and ileum. Biochim Biophys Acta 554:430-440

17. Vaughn WK, Neal RA, Anderson AJ 1976 Computer estimation of the parameters of the sigmoidal kinetic model. Comput Biol Med 6:107

18. Van Voorhis K, Said HM, Ghishan FK, Abumrad NN 1989 Transport of glutamine in rat intestinal brush border membrane vesicles. Biochim Biophys Acta 978:51-55

19. Kimberg MS, Handlogten ME, Christensen HN 1985 Characteristics of amino acid transport system in rat liver for glutamine, asparagine, histidine and closely related analogs. J Biol Chem 255:4011-4019

20. Stevens BR, Kautnitz JR, Wright EM 1984 Intestinal transport of amino acids and sugars: Advances using membrane vesicles. Ann Rev Physiol 46:417433

21. Stevens BR, Ross HJ, Wright EM 1982 Multiple transport pathways for neutra amino acids in rabbit jejunal brush border vesicles. J Membr Biol 66:213225

22. Windmueller HG, Spaeth AE 1975 Intestinal metabolism of glutamine and glutamate from the lumen as compared to glutamine from blood. Arch Biochem Biophys 171:662-672

23. Taylor PM, Egan CJ, Rennie MJ 1989 Transport of glutamine across blood facing membranes of perfused rat jejunum. Am J Physiol 256:E550-E558

24. Sevdalein DA, Ozand PT, Zeilke HR 1980 Increase in glutaminase activity during the growth cycle of cultured human diploid fibroblasts. Enzyme $25: 142-144$

25. Pinkus LM, Windmueller HG 1974 Phosphate dependent glutaminase of the small intestine. Localization and role in intestinal glutamine metabolism. Arch Biochem Biophys 182:506-517

26. Murer H, Kinne R 1980 The use of isolated membrane vesicles to study epithelial transport processes. J Membr Biol 55:81-95

27. DeSmedt H, Kinne R 1981 Temperature dependence of solute transport and enzyme activated in hog renal brush border membrane vesicles. Biochim Biophys Acta G48:247-G253.

28. Kimura RE 1987 Glutamine oxidation by developing rat small intestine. Pediatr Res 21(2):214-217

29. Bulus NM, Abumrad NN, Ghishan FK 1989 Characteristics of glutamine transport in dog jejunal brush border membrane vesicles. Am J Physio 257:G80-G85 